\title{
Is the European Commission Really in Decline?
}

\author{
NEILL NUGENT ${ }^{1}$ and MARK RHINARD ${ }^{2}$ \\ ${ }^{1}$ Manchester Metropolitan University. ${ }^{2}$ Stockholm University and the Swedish Institute of International Affairs
}

\begin{abstract}
In the academic debate on the relative powers and influence of the EU institutions, it has become common to suggest - especially in the case of advocates of the 'new intergovernmentalism' - that the European Commission is in decline. In this article we show that while in some limited respects this is indeed the case, the Commission's overall position in the EU system is not one of having become a weaker institutional actor. The extent of the losses of its powers and influence tends to be exaggerated, while in some aspects its powers and influence have actually been strengthened. We show this by focusing on three of the Commission's core functions - agenda-setter, legislative actor and executive - all of which are widely portrayed as being in decline. We incorporate into our analysis both the formal and informal resources available to the Commission in exercising the functions.
\end{abstract}

Keywords: agenda-setting; European Commission; European Union; executive tasks; legislative functions; supranational

\section{Introduction}

Most recent scholarly studies of the Commission and of the balance of power between EU institutions conclude that the Commission's powers and influence are in a general state of decline (see, for example, Kassim et al., 2013; Majone, 2014; Rasmussen et al., 2013; Wallace and Reh, 2015).

The 'decline of the Commission' thesis features particularly prominently in the 'new intergovernmentalism' agenda, which involves ambitious new theorizing about the nature of collaborative decision-making in today's EU. At the heart of the new intergovernmentalism is the suggestion that since the Maastricht Treaty there has been a 'tendency towards European integration without supranationalism ... predicated on an increasingly deliberative and consensual approach to EU decision-making [by the representatives of Member State governments]' (Bickerton et al., 2015a: 1; see also Bickerton et al., 2015b). Three features of this new approach to decision-making are seen to impact negatively on the powers and influence of the Commission. First, the emergence of deliberation and consensus as the 'dominant behavioural norms' (Bickerton et al., 2015a: 2) have resulted in EU policy-making, at all stages, becoming more Council-based. Viewed from this perspective, the Commission has become a less important and less ambitious agenda-setter as compared to previous eras, has become more timid in putting forward common policy solutions and has increasingly become instructed on what to do by the European Council - which has emerged as 'a centre for governing major new areas of EU activity and crisis management' (Bickerton et al., 2015a: 2). Second, the importance of the Commission's legislative roles has declined. As part of this, there has been, on the one hand, a decline in the use of legislation for advancing policy activities and a corresponding decline in the use of the Community method (where the 
Commission's powers are strong) and, on the other, an increase in non-legislative policy measures and an accompanying increase in various forms of intergovernmental-based decision-making processes (where the Commission's powers are relatively weak). Third, the Commission's executive powers have declined, in particular as a result of a change in the delegation of powers by the European Council and Council away from the Commission (and the Court) to new agencies and other de novo bodies.

In this article we question whether the Commission really is in decline. In doing so, we structure our analysis around the three just-listed features of new intergovernmentalism, namely the claimed decline in the Commission's core agenda-setting, legislative and executive powers. However, we must stress that it is not our intention to offer a general critique of new intergovernmentalism (for such critiques, see Bulmer, 2015; Schimmelfennig, 2015). We must also emphasize that while we focus particularly on the points made about the Commission in the new intergovernmentalism literature, we do not ignore the positions of other commentators who have also noted a decline in the Commission's powers and influence. Kassim et al. (2013), for instance, have noted the significance of the continued strengthening of the EP's powers since Maastricht - a development that is not given much attention by new intergovernmentalism. In the view of Kassim et al., this strengthening has been achieved 'largely to the detriment of the Commission' (Kassim et al., 2013, p. 132).

We seek to show throughout the article that arguments regarding the Commission's decline tend to be overstated and deserve to be challenged. An important reason why the decline is overstated is that proponents of the decline argument are primarily concerned with formal changes in the Commission's position in EU decision-making processes and do not give sufficient attention to the informal power resources it has at its disposal. We give examples of these informal resources at appropriate points throughout the article.

Our position thus is that while there certainly have been changes in the Commission's powers and influence over the years, they have by no means all been in a declining direction. Rather, in some respects the Commission's positions have even been strengthened.

\section{The Commission and Agenda-Setting}

Agenda-setting involves creating a situation whereby an issue is in a position to be considered by policy-makers. As such, it is normally more general in scope and precedes in the policy cycle the other two functions - legislative and executive - considered in this article.

A common suggestion in the literature is that the Commission has lost its role in driving the EU's agenda. In this section we show that while it is true that the Commission's agenda-setting position has been compromised in recent years, largely because of the arrival of new posts in the EU's leadership landscape, its influence remains strong.

The Commission enjoys several treaty-based powers that contribute to its enduring agenda-setting ability. These include provisions requiring it to act as 'guardian of the treaties', the 'catch-all clause' of Article 352 TFEU allowing it to propose laws to attain objectives set out in the treaties (a clause widened in applicability by the Lisbon Treaty) and, most importantly, the responsibility set out in Article 17(1) TEU requiring it to "promote the general interest of the Union and take appropriate initiatives to that end'. This latter article, which is deliberately phrased in a vague manner, permits the Commission to move on a broad front if it so wishes - by, for example, issuing position or discussion papers which 
are designed to set or shape the agenda. If the ideas expressed in such papers are then endorsed by other institutions, especially by the European Council and/or the Council, or if they lead to requests for the Commission to develop its thinking further, perhaps in the form of a Communication, they become partly 'legitimized' and can be used to develop frameworks in which more specific proposals are advanced. Such has occurred recently with energy policy, which has been promoted by the Commission for many years but which was given a considerable boost by the European Council's June 2014 issuance of a 'Strategic Agenda for the Union in Times of Change' (European Council, 2014a). The Strategic Agenda set out five priority areas for the next five years - one of which was 'Towards an Energy Union With a Forward-Looking Climate Policy'. The October 2014 summit Conclusions were then studded with invitations and/or instructions to the incoming Juncker Commission to do an array of things in respect of particular aspects of the energy/climate change area (European Council, 2014b). The Juncker Commission was thus given considerable authority to be highly pro-active in this policy area: an authority of which it quickly took advantage with the issuing, in February 2015, of a strategy based on five themes with the aim of creating 'a resilient Energy Union with an ambitious climate policy at its core ... to give EU consumers - households and businesses - secure, sustainable, competitive and affordable energy' (Commission 2015c: 2).

Treaty powers thus allow the Commission to help set the EU's agenda to a considerable degree. So do a variety of informal resources. One such resource consists of political skills, honed over decades, to take advantage of windows of opportunity and to use seemingly innocuous policy instruments to promote significant expansions of the EU's policy agenda. (On the importance of windows of opportunity as enablers of major policy initiatives, see Kingdon, 1984; Princen, 2009.) As Cram observed more than 20 years ago, the Commission is a 'purposeful opportunist' - that is, 'an organisation which has a notion of its overall objectives and aims but is quite flexible as to the means of achieving them' (Cram, 1994, p. 214). In acting as a purposeful opportunist to expand the scope of Union competence (and, in so doing, also its own scope for action), the Commission has employed a variety of techniques that are designed to make its policy ideas acceptable. So, for, example, it has played a part in focusing political discourse on the merits of policy actions at the EU level rather than at national levels - as with the internal market and the environment, where it has virtually run public relations campaigns and where Commission representatives, especially Commissioners, have actively engaged in public debate. Another sort of discourse has seen the Commission citing successes in existing policy areas to justify developments in other policy areas - 'agenda-setting through linkages'. An example of this sort of discourse is the relating of benefits that are claimed to have accrued from the existing internal market programme to the benefits it is suggested will also accrue if the programme is further extended. Such a discourse has, for example, long emanated from the Commission in respect of the further liberalization and opening up to more competition of public utilities. A similar discourse is now also being heard in respect of the Juncker Commission's aims for a fully functioning Capital Markets Union to be in place by 2019 - with the opening of this 'campaign' being the issuing of a Commission Green Paper in February 2015 (Commission, 2015b) and an action plan in September 2015 (Commission, 2015c).

By combining its formal and informal leadership resources, the Commission has thus been able to help shape the agenda and exert influence in many key policy areas, as the 
following examples - deliberately drawn from very different policy spheres - show. (Further examples are given in Nugent and Rhinard, 2015.)

- Industrial policy was initially slow to appear on the EU's agenda, but since the Commission issued a communication on the subject in 1990 (Commission, 1990), it has featured openly and prominently. Working closely with business and stakeholders, the Commission has been highly active in trying to create a more interventionist industrial policy at EU level and to this end has advocated and promoted a range of policy developments. So, for example, between 2010 and 2014 it issued no less than three communications setting out its views on what should be the EU's approach to and priorities for industrial policy (Commission 2010a, 2012, 2014a). Central themes in the communications included the need for a tighter integration of the many dimensions of industrial policy, the further integration of network-based and infrastructure industries and the convergence of information and communication technologies.

- On becoming European Commission president-elect in July 2015, Jean-Claude Juncker sought to persuade EU decision-makers in the European Council, the Council and the EP that there was an urgent need to generate a momentum behind increased investment within the eurozone. To this end, he called for the creation of a new investment fund, capable of generating some $€ 300$ billion of 'new money'. Soon after the new College assumed office in November 2014, a Commission communication was issued detailing the nature and purpose of the fund (Commission, 2014b). It was now labelled the European Fund for Strategic Investments (EFSI), the target figure was set at $€ 315$ billion and it was to be used primarily for investing in infrastructure projects related to transport, energy, information technology and trading. The fund involved new financial thinking in the EU context as it was to be only marginally based on existing EU financial resources: a $€ 16$ billion guarantee from the EU budget and a $€ 5$ billion contribution from the European Investment Bank (EIB) were to serve as leverage to raise the rest of the money from Member States and on capital markets. The investment plan was approved in principle by the European Council in December 2014, which enabled the Commission to issue in January 2015 a proposal for a regulation to give the EFSI legal effect (Commission 2015a).

- In 2000 the Lisbon Strategy was launched, which was a ten-year programme for promoting growth, competitiveness and employment based mainly on soft (that is, nonlegislative) policy instruments. However, it increasingly became recognized that the Strategy was not achieving its goals, despite its being substantially revised in 2005 . This resulted in the projected revision and renewal of the Strategy at the end of the decade being viewed by most policy actors with both caution and scepticism. By 2009, negotiations on the Lisbon Strategy's successor were virtually stalled. At this point, as Copeland and James (2014) show, the Commission took advantage of two overlapping windows of opportunity to reframe the Strategy. One of these windows was provided by the sovereign debt crisis, about which Member State governments were uncertain and divided as to how to respond. The other window was provided by shifting institutional dynamics, which saw a new College of Commissioners just installed, responsibility for economic policy within the Commission becoming more centralized in DG ECFIN, and post-Lisbon Treaty institutional arrangements not yet settled. 
The reframing of the Strategy included shifting the balance in the Commission's initial proposals away from the intended enhancement of social and environmental concerns towards a much greater emphasis on strengthening the mechanisms of economic surveillance so as to help provide an exit strategy from the sovereign debt crisis by prioritizing fiscal sustainability and macroeconomic stability. The Commission's revised approach - which saw it acting in a classical 'purposeful opportunist' manner - laid the bases for its March 2010 Europe 2020 Communication (Commission, 2010a), which was subsequently accepted by the European Council. As Copeland and James (2014, p. 14) summarize: 'we find that the Commission served as the principal source of ideas behind Europe 2020 and the motor driving the agreement.' In a similar vein, Armstrong (2012, p. 214-15) has stated: 'Europe 2020 emerged as a European Commission project, personally associated with its president ... Indeed, the 2020 strategy and wider economic governance reforms were key both to the political objectives of the new Commission and to a sense that "Europe" was capable of acting in the midst of the financial crisis.'

- Although the 1957 EEC Treaty explicitly identified transport as a policy area to be developed 'within the framework of a common transport policy' (Article 74 EEC), there were few significant integrationist advances until the mid-1980s. Railways were particularly left to the side, except in so far as measures were adopted to exclude them from 'normal' market requirements (see Stevens, 2004). However, since the early 1990s the Commission has sought to lead the (still often reluctant) Member States in the direction of building a more competitive and more genuinely trans-European railway system. It has taken a step-by-step approach, much of it stemming from a policy core of separating infrastructure from operations. As Dyrhauge (2013) has put it: 'Overall, the Commission, as a policy entrepreneur and strategic actor, has been able to direct EU railway policy-making towards its preferred governance structure.'

Given the complexity of EU processes it is, of course, often virtually impossible to disentangle policy contributions and determine with precision which institution(s) and actor (s) did what and, in so far as they did do something, the extent to which they did it on their own volition and in an autonomous manner. We thus readily acknowledge that many initiatives and proposals issuing from the Commission find their origins in preferences and wishes first expressed elsewhere, not least by Member States on an individual and/or on a collective basis in the European Council or the Council. However, the fact is that there is an abundance of empirical evidence to suggest that in launching initiatives and framing proposals in important policy areas the Commission is frequently doing much more than simply responding in an automatic manner to external pressures. Rather, it is often offering an at least quasi-independent lead itself (see, for example, Burns, 2004; Rhinard, 2010). Moreover, no matter from where the original ideas for initiatives or proposals may stem, once the Commission begins working on them it can do much to frame the terms in which they are considered, when they are considered, by whom they are considered, and with what receptivity they are considered.

Is it thus correct to say, as much of the literature suggests, that the Commission's agenda-setting power has declined? It cannot be denied that the Commission's once commanding position in driving the EU's agenda has been challenged by other institutional 
actors. The EU's responses to the post-2008 economic and financial crises illustrate this, for while the Commission has been fully associated with the responses, individual Member States (especially Germany) and the ECB (European Central Bank) also have been to the fore in advancing 'solutions', while Member States collectively have occasionally turned first to the President of the European Council to co-ordinate action and present solutions. Thus, in the spring of 2010, shortly before the Commission was due to present a communication on enhancing economic policy co-ordination and tightening fiscal discipline, the March European Council meeting asked its president, Herman Van Rompuy, to chair a task force to 'present to the Council, before the end of this year, the measures needed to reach the objective of an improved crisis resolution framework and better budgetary discipline, exploring all options to reinforce the legal framework' (European Council, 2010). (In the event, the contents of the Commission's communication (Commission, 2010b) and of the task force (Task Force, 2010) were - unsurprisingly - very similar).

However, the debilitating effect of the arrival of new would-be institutional leaders - of which the European Council President is the most notable - on the Commission's agendasetting power should not be overstated. One reason for this is that the Commission has never had a wholly free hand in setting the EU's agenda. Rather, there have long been variations in the agenda-setting leadership it has provided, as regards both time periods and policy areas. The Commission's failure to make inroads in common taxation policies serves as just one example (Wasserfallen, 2014). Another reason is that in many respects the Commission has adapted to the role of the President of the European Council fairly well, seeking out complementary rather than conflicting roles. During the EU's response to the sovereign debt crisis, for example, the Commission and European Council Presidents worked relatively harmoniously with each other and did not display overt political bickering. According to information given to us in interview by a Council Secretariat insider, this was largely because the European Council President seconded many of his staff from the Commission. This last point shows how, even after the recent changes to the EU's institutional architecture, the Commission remains the main EU repository of policy arguments, ideas, expertise and memory - as the high policy activism of the Juncker Commission has demonstrated in respect of such pressing and varied challenges facing the EU as the Mediterranean migration crisis, the Greek bailout crises, and the increasingly perceived need to build a single digital market.

The Commission's ability to set the normative terms of a debate, to offer policy-shaping ideas and to provide historically informed solutions thus belies claims of its reduced relevance in shaping outcomes.

\section{The Commission and Legislating}

The second claim that we question in the 'decline of the Commission' literature is that the Commission's role in shaping legislation is not as important as it used to be. This is usually attributed to a fall in the volume of legislation and to an increased involvement of other actors in the making of legislation. While we readily acknowledge that these developments have occurred, we suggest that they have not been as damaging for the Commission as they initially appear.

\section{A Fall in the Volume of Legislation}

Unquestionably there has been a considerable fall in the volume of EU legislation in recent years. Focusing here just on directives - which is the form most politically significant 
and contested legislation takes - in the early 2000s there were, on average, more than 100 such legislative initiatives coming from the Commission per year, whereas today there are just a handful. For example, of the 29 new initiatives outlined by the outgoing Barroso Commission in its Work Programme for 2014, just four were legislative proposals, nine were a mixture of legislative and non-legislative actions (so they would not necessarily involve legislation) and 16 were non-legislative initiatives (Commission, 2013). (In the event, 14 new directives were passed in 2014.) In its Work Programme for 2015, the incoming Juncker Commission proposed 23 new initiatives, of which just five were legislative proposals, nine were a mixture of legislative and non-legislative actions and nine were non-legislative initiatives (Commission, 2014d).

This fall in the volume of legislation is seen by those who support the 'decline' argument as being significant primarily because of the Commission's near-monopolistic initiating power in respect of legislation and its sharing of such power in respect of non-legislative actions. Increasing use of the latter for EU policy development - most particularly through various forms of NMG (new modes of governance), especially the OMC (open method of coordination) - is thus thought to damage the Commission's position. However, this formal distinction in the Commission's initiating powers in respect of legislative and non-legislative actions is not so significant in practice because, irrespective of the type of action proposed, the Commission is almost invariably the best placed policy actor to launch initiatives and to make proposals. Virtually all EU policies that are based on some mixture of co-ordination, co-operation and 'soft law' have their origins in Commission proposals and documents (see Nugent and Rhinard, 2015, chapter 9).

Another point of relevance here is that although the volume of legislation has fallen, the EU's remit to make legislation under the Community method has been expanded by rounds of treaty reform. The Commission's legislative powers may thus be said to have been expanded. Even policy areas that 'are clearly part and parcel of the hard kernel of member states' area of sovereign authority' (Dehousse 2013, p. 3) have come into the Community method's reach, including many dimensions of the AFSJ (area of freedom, security and justice) and small but expanding policy areas such as civil protection co-operation (Boin et al., 2013).

\section{Increased Involvement of Other Actors in the Making of Legislation}

The involvement of other actors, especially the EP, in the making of legislation has grown over the years. However, the Commission's strength remains formidable, at both initiation and decision-taking stages. Looking closely at both stages allows us to see that recent institutional and process changes have not resulted in a significant decline of the Commission's position or powers.

\section{Legislative initiating}

The Commission's almost exclusive, treaty-based power to propose and draft legislation remains firmly intact. In only one policy area may other actors propose actual legislation: judicial co-operation in criminal matters and police co-operation, in which a quarter of the Member States may initiate laws (Article 76 TFEU). In all other areas, the right of other institutions in the legislative initiation process is confined to making requests for new proposals - and in no areas is the Commission formally obliged to act upon such requests. 
What has changed in recent years is a slightly more onerous obligation placed upon the Commission in situations in which it chooses to ignore requests. Under the Lisbon Treaty, it 'shall inform the Council of the reasons' (Article 241 TFEU) for not taking action and an inter-institutional agreement requires that it similarly notifies the Parliament (Commission and European Parliament, 2010).

A new measure introduced by the Lisbon Treaty that initially was thought might pose a significant challenge to the Commission's initiating power was the right of EU citizens to request Commission action under the ECI (European Citizens' Initiative). The right can be exercised by submitting a petition with not less than one million signatures by nationals from at least seven EU Member States (with a specified minimum number of signatories being required in each of the seven states). However, as with Council and EP requests, the Commission is not under an obligation to respond positively, and in practice it has not done so, with almost half of the 49 initiatives submitted up to May 2015 being deemed by the Commission to be inadmissible because they fell outside its powers and with only three - on the public right to water, on not funding research using human embryos and on stopping vivisection - having completed the process by gathering the required number of signatures and being accepted by the Commission. Of these three, only one - the Right2Water ECI - has to date received a positive Commission reaction, and even this was just in the form of promising a study rather than proposing new legislation as was requested (Commission, 2014c).

The Commission has thus not formally become more constricted in its right of initiative or more bound to abide by the wishes of other would-be legislative initiators. That said, it is true that against the backdrop of the post-2008 crises other policy actors, and the European Council in particular, have sought to give the Commission clearer guidelines as to what sort of legislative measures it should be developing. Indeed, Bocquillon et al. (2013, p. 2) go so far as to suggest that 'the European Council has taken a central place in the decision-making process under the legislative procedure. This is apparent in its increasing interventionism in the policy-making process, often taking over the right of initiative of the Commission on sensitive policy issues' (italics in the original). Ponzano et al. (2012, p. 37) indicate something similar in respect of the Council and $\mathrm{EP}$, arguing that 'the European Commission has increasingly taken over the responsibility to present proposals as "indicated" by the co-legislators".

However, two important points need to be kept in mind here concerning the (alleged) increasing legislative initiating activities of other institutional actors. First, the Commission has never initiated legislative proposals solely on the basis of its own ideas and preferences. There is nothing new, for example, about the European Council or the EU Council issuing what amount to directions, bordering on instructions, to the Commission regarding the submission of proposals. But those directions, in European Council Conclusions for instance, have often been inserted on the initiative of the Commission, which has then used the endorsements of the governmental leaders to inject political momentum behind its own policy ideas. Second, the 'power of the pen' should not be trivialized, for it gives first mover's advantage over the other institutions (Hartlapp et al., 2014; Versluis et al., 2011, p. 134). While it is true that the Commission does not have complete discretion over what and when legislative proposals are to be initiated, its drafting powers do mean it largely controls how proposals are shaped, framed and articulated (Princen and Rhinard, 2006). 


\section{Legislative decision-taking}

Once drafts have been approved by the College and have thus officially become legislative proposals, the Council and the EP come to the fore as the formal decision-takers. This, of course, means that their views on the contents of proposals are extremely important in determining which legislative proposals eventually become law, and in what form (see Hix and Høyland, 2013 and Huber and Shackleton, 2013 on the EP; and Bailer, 2014 and Häge and Naurin, 2013 on the Council).

But the Commission's powers and influence remain considerable, as a brief look at its position in the most used legislative procedure - the ordinary procedure - shows. The structural nature of the procedure encourages the EP, the Council and the Commission to engage in extensive inter-institutional bargaining before and during each of the possible three readings, with the Commission having significant powers to bring to bear at each reading. Among its informal powers are ones stemming from: its physical presence at all legislative stages (which give it an excellent knowledge of what the EP and the Council want and may settle for - the 'win set', in the language of game theory); the perception of it as a (near) neutral facilitator that can be used to help mediate conflicts; and its command of expert and technical information that the EP and the Council often do not have - which often enables it not only to find compromises that the Council and EP can accept but also to preserve its own preferences and interests in doing so (Blauberger and Weiss, 2013).

Among the Commission's formal powers during decision-taking, two are especially important. First, it can amend proposals as they proceed. The Commission has, and uses, this power, but where EP-Council deliberations result in a compromise the Commission tends to follow suit and to make its amendments accordingly. Second, the Commission can withdraw proposals at any time prior to Council adoption. In practice, 'technical' withdrawals - which occur usually because of some sort of obsolescence or because circumstances have overtaken the rationale or contents of the proposal - are common and are not contested. 'Political' withdrawals take two forms and are more controversial: the first form is when the Commission decides there is no prospect of the legislators agreeing to a proposal; the second form occurs when the Commission feels the original purpose of the proposal has been emasculated by the legislators. Though rarely used, this second form does, nonetheless, give the Commission a useful 'threat' power. It is a power that was bolstered in April 2015 when the CJEU (Court of Justice of the European Union) ruled in the Commission's favour in a case brought by the Council against the Commission for having withdrawn a legislative proposal in May 2013 because the proposal's original rationale had been undermined by the Council and EP (case C-409/13). The Court ruled that the Commission's right to withdraw legislative proposals is inseparable from its right of initiative and that the Commission's role within the ordinary legislative procedure is not confined to that of honest broker.

The proportion of proposals that are agreed at first reading stage has greatly increased over the years, reaching 85 per cent (422 out of a total 495 proposals) over the lifetime of the 2009-14 Parliament (European Parliament, 2014a). Over the same period, 13 per cent of proposals ( 65 of the original total of 495 proposals) were agreed by the end of the second reading. This very high number of first (especially) and second reading adoptions is to the Commission's advantage, as it means there are fewer rounds of direct EP-Council bargaining and, therefore, fewer opportunities for the EP and Council to reject and/or amend Commission legislative proposals. 
The Commission's position at the third legislative stage of the ordinary procedure - conciliation - is weaker than it is during the first two stages. This is because during conciliation the Commission cannot withdraw proposals and, unlike during the first two stages of the procedure, amendments to which it is opposed do not require unanimous approval in the Council to be overridden. These more restricted powers are often cited as reasons for the Commission's supposed legislative decline (see, for example, Costello and Thomson, 2013). However, their significance has to be placed in the context of the increasing adoption of proposals at first and second readings, which has naturally resulted in the conciliation stage being less needed and used. Indeed, during the 2009-14 Parliament only 2 per cent of proposals (just eight) entered conciliation (European Parliament, 2014a).

There is some substance to the legislative decline claim, especially in that under the ordinary procedure the Commission does have to be more sensitive to the EP's preferences and no longer enjoys the 'privileged relationship' with the Council it once held. In practice, however, it is very rare for Commission proposals to be completely rejected in the legislative process, and in the great majority of legislative negotiations the detailed content of most Commission texts survive into the final legislative acts. This success is partly explained by the Commission anticipating reactions in the Council and EP, but far from being a recent development, this is something the Commission has long done.

Even in respect of the EP's increased powers, the EP and Commission often share broadly overlapping and integrationist-oriented preferences. In addition, EP rapporteurs and Commission officials normally enjoy good relations, a fact that is not usually noted by those who make claims of the Commission's decline vis-à-vis the EP. But these relations are an aspect of the Commission's many informal legislative resources, which give it the possibility of reframing arguments in line with shifting circumstances (Rhinard, 2010) and strategically influencing the 'tabling of adoption and amendments of compromise texts' (Rasmussen, 2003, p. 9).

Overall, the evidence thus seems to indicate that the claim of declining legislative roles for the Commission is overstated.

\section{The Commission and Executive Tasks}

The third area in which we question the Commission's purported decline concerns its executive tasks. The Commission exercises many types of executive functions, ranging from ruling on whether or not proposed mergers between large companies should be permitted to monitoring the application by Member States of the rules of the Common Fisheries Policy. In this section we look at two of the Commission's executive functions - fiscal manager and maker of non-legislative acts - and then we examine how the rise of new bodies and agencies affects the Commission's roles and influence in undertaking executive functions.

\section{Fiscal and Financial Manager}

The Commission's fiscal and financial management responsibilities have been considerably strengthened in response to the post-2008 economic, financial and eurozone crises. These increased responsibilities have been provided for in several legal instruments, of which the best known is the 2012 Treaty on Stability, Coordination and Governance in the Economic and Monetary Union - more commonly known as the Fiscal Compact 
Treaty. Signed by all EU Member States other than the Czech Republic and the UK, at the heart of the Treaty is a tighter version of the SGP (Stability and Growth Pact) which, among other things, places legally binding limitations on national budget deficits and debts. Under the Fiscal Compact Treaty and related legislation, the Commission is assigned very considerable and extensive economic and financial management responsibilities and powers, especially within the eurozone: responsibilities and powers that are not just of an administrative kind but that have potentially very significant political, economic and social implications. These include: maintaining a constant surveillance and monitoring of national economic performances, policies and budgetary plans (as part of this, there are officials in all of the Commission offices in the member states charged with this responsibility); and an ability to issue sanctions if Fiscal Pact signatories do not comply with requirements and recommendations - subject to a Council decision, by 'reverse' qualified majority vote, not to apply the Commission's suggested sanction(s). As Bauer and Becker (2014, p. 215) put it in their examination of the institutional consequences of the crises, the Commission's tasks have been 'undergoing a profound change. But rather than being in decline, it is entrusted with ever wider and deeper implementation tasks that are of high political importance ... its role in the reformed economic governance architecture appears not to be diminished but strengthened.'

\section{Maker of 'Non-Legislative Acts'}

One of the Commission's more substantial powers stems from its ability to adopt 'nonlegislative acts' which, despite their confusing name, carry the force of law (akin to administrative rule-making at national levels). Of the 1500-2000 basic (that is, not including amending) legally binding instruments that are normally issued by the EU each year, about 70 per cent are Commission acts. In 2014 such acts consisted of some 866 regulations, 271 decisions, and 14 directives (Eur-Lex, 2015).

Law-making in this form has been delegated to the Commission because EU legislation typically sets only the broad goals that a law is meant to accomplish. The Commission must then flesh out details, update for technical progress and account for contextual changes (such as shifts in market conditions) by adopting 'non-legislative' acts. Since these decisions often have great import to Member States, governments have designed a complex set of arrangements to oversee the Commission. These arrangements have included Member Statecomprised committees - formerly called 'comitology' committees - exercising different levels of control over the Commission (see Hardacre and Kaeding, 2011).

The Lisbon Treaty changed comitology to the Commission's advantage. Separate procedures were created for overseeing the Commission's adoption of two different kinds of acts. The first are called delegated acts and are of 'general application to supplement or amend non-essential elements' of the original law (Article 290 TFEU). The potential for delegated acts to amend original laws (and thus potentially generate new legal constraints) has resulted in comitology committees being replaced with a post hoc control procedure by which, after the adoption by the Commission of a delegated act, the Council and Parliament have the right to directly intervene and reject the act. While this may seem like a powerful control mechanism, in practice the Commission gains considerable latitude, for not only does it no longer need to consult a comitology committee in advance of adopting a delegated act, but the political mobilization and attention to detail required 
by the Council and Parliament to overturn a delegated act makes it unlikely that they will do so. Indeed, from the entry into force of the Lisbon Treaty until the end of 2014 the Council and the Parliament each rejected only one delegated act out of approximately 200 adopted over that period (Eur-Lex search; see also Voermans et al., 2014; European Parliament, 2014b).

The second type of act created by the Lisbon Treaty are implementing acts, which are used when specifications are required for the uniform application of the original law (Article 291, TFEU; see also Regulation (EU) No 182/2011). Thus, in principle, implementing acts specify what Member States need to do in order to implement the original law and do not create new legal obligations (see Christiansen and Dobbels, 2013). In these cases, aspects of the old comitology system remain in place, but the number of procedures used has been reduced to two: the advisory procedure (in which the Commission is only obliged to take a committee's opinion into account) and the examination procedure (allowing a simple majority of Member States on a committee to reject a proposed implementing act, and allowing the Council or Parliament to pass non-binding resolutions if either feels the Commission is consistently exceeding its rule-making powers). While these reforms represent significant changes, they do not reflect a Commission decline since the practice in committees is much the same as it was in the past history of comitology: from the approaching 4000 implementing acts adopted between 2009 and 2014 (about two thirds of Commission legislation takes the form of implementing acts), there were very few Commission defeats - not least because implementing legislation is not usually put to the vote if the Commission judges it will not be approved.

\section{Agencies and the Commission's Executive Powers}

Since the 1970s, but more especially since the early 1990s, a wide variety of European agencies have been created. These agencies come in different forms, but are mainly of two broad types: decentralized, or regulatory, agencies, of which there are (as of autumn 2015) more than 30, and executive agencies, of which there are six. The former, which have a wider range of tasks to perform, are sometimes seen as having contributed to the Commission's supposed decline because they were primarily created to relieve work pressure - especially executive work pressure - on the Commission and/or to bring subject specialists together in a less political and less centrally controlled working environment than exists in the Commission.

Much academic research has been conducted on agencies, including on their relations with the Commission (see, for example, Busuioc et al., 2012; Egeberg et al., 2015; Rittberger and Wonka, 2011). A central finding to emerge from this research is that far from agencies having damaged the Commission's position in the EU's institutional system, in some ways they have actually strengthened it. This is because they relieve the Commission of many routine executive tasks, while making greater expertise available to it. Moreover, they do so within a context where virtually all agencies are subject to various forms of Commission control. This has resulted in the Commission being largely unconcerned about the institutional implications for it of the agencies that have been established to date and taking, as Peterson (2015, p. 186) puts it, a 'pragmatic view' of the creation of new agencies.

Similarly, other kinds of de novo institutions have not presented so severe a challenge to the Commission as is often suggested. The EEAS (European External Action Service), 
for instance, was seen initially by some observers as a 'threat' to the Commission, but even before the EEAS was established the Commission was successful in taking steps to retain control over such key external policy areas as trade, development and humanitarian aid (Nugent and Rhinard, 2013). Further, Commission president Jean-Claude Juncker has brought the High Representative, who heads the EEAS and who is also a Commission Vice-President, much more within Commission structures. As for the much-discussed ESM (European Stability Mechanism), which provides funding opportunities to eurozone Member States in financial difficulty, it is not the Commission's ideal institutional outcome, but it does rely heavily on Commission input and, like the EEAS, it is largely responsible for tasks not previously undertaken by the Commission (Bauer and Becker, 2014).

In this section on the Commission and executive tasks, we have reviewed a wider span of executive functions than is normally considered in assessments of the Commission's assumed overall decline and have shown some of the functions to be strengthening rather than weakening (as similarly shown by Wille, 2013). In the area of fiscal and financial management, the economic and sovereign debt crises have served to give the Commission new responsibilities, notably via the Fiscal Compact Treaty and related legislation. In the area of administrative law-making, reforms to the former comitology system have loosened some of the restrictions previously placed on the Commission. And as for the emergence of agencies - which is where most of the decline literature is focused as regards executive functions - they have had, if anything, a marginally strengthening effect on the Commission's powers and influence.

\section{Conclusions}

It has been argued in this article that the Commission's powers and influence in the EU system have not declined as much as is commonly suggested or assumed. Certainly there has been a slight decline in some respects, but in others the Commission's position in the EU system is either much as it has long been or has even been strengthened.

More specifically, of the three traditional Commission functions we have examined in the article, the one that has been most affected by recent changes is general agenda-setting. But even it has been only marginally diminished with, in most spheres of 'Community' business, virtually all agenda-setting continuing to be undertaken by the Commission - operating either directly or indirectly (that is, via other EU institutions, most notably the European Council). As for the other two traditional functions - legislative and executive - the supposed decline is even less evident. While the ordinary legislative procedure has introduced new voices and preferences in the decision-making process, the Commission's initiation role and its role in shaping decision-taking largely obviate any 'losses'. Regarding, for example, its role in shaping decision-taking, making use of its presence at all stages of the legislative process, the Commission strategically considers the framing and timing of proposals and amendments and helps to negotiate compromises that are often favourable to its own interests. In so doing, it deploys a range of formal and informal resources that are at its disposal - with the latter bringing into play a dimension of the Commission's potential influence and power that, as was suggested in the introduction to this article, is often left out of accounts of the Commission's decline but which, in practice, is of considerable importance. Finally, the Commission's executive functions have not 
declined in any significant way. In fact, the financial and eurozone crises (in the case of fiscal and financial management), the Lisbon Treaty (in the case of the making of administrative law) and the creation of agencies have served to empower the Commission.

Thus, the oft-made claims that the Commission is in decline, most recently articulated in arguments regarding the emergence of a form of 'new intergovernmentalism', are challengeable.

Correspondence:

Mark Rhinard

Department of Economic History

Stockholm University

SE-106 91 Stockholm

Sweden

email: Mark.Rhinard@ui.se

\section{References}

Armstrong, K.A. (2012) 'The Lisbon Strategy and. Europe 2020: From the Governance of Co-ordination to the Co-ordination of Governance'. In Copeland, P. et al. (eds) The EU's Lisbon Strategy: Evaluating Success, Understanding Failure (Basingstoke: Palgrave Macmillan), 208-28.

Bailer, S. (2014) 'An Agent Dependent on the EU Member States? The Determinants of the European Commission's Legislative Success in the European Union'. Journal of European Integration, Vol. 36, No. 1, pp. 37-53.

Bauer, M.W., et al. (2014) 'The Unexpected Winner of the Crisis: The European Commission's Strengthened Role in Economic Governance'. Journal of European Integration, Vol. 36, No. 3, pp. 213-29.

Bickerton, C., et al. (2015a) 'The New Intergovernmentalism and the Study of European Integration'. In Bickerton, C. et al. (eds) The New Intergovernmentalism: States and Supranational Actors in the Post-Maastricht Era (Oxford: Oxford University Press), pp. 1-48.

Bickerton, C., et al. (2015b) 'The New Intergovernmentalism: European Integration in the PostMaastricht Era'. JCMS, Vol. 53, No. 4, pp. 703-22.

Blauberger, M., et al. (2013) “'If You Can't Beat Me, Join Me!” How the Commission Pushed and Pulled Member States into Legislating Defence Procurement'. Journal of European Public Policy, Vol. 20, No. 8, pp. 1120-38.

Bocquillon, P., Braun, J.F., Carafa, L., Dobbels, M., and Perez de Leon, C.G. (2013) 'InterInstitutional Coordination in the EU: Reassessing the Legislative Balance of Power After Lisbon'. Paper presented at INCOOP dissemination conference, Brussels, 11 October.

Boin, A., Ekengren, M. and Rhinard, M. (2013) The European Union as Crisis Manager: Patterns and Prospects (Cambridge: Cambridge University Press).

Bulmer, S. (2015) 'Understanding the New Intergovernmentalism: Pre- and Post-Maastricht EU Studies'. In Bickerton, C. et al. (eds) The New Intergovernmentalism: States and Supranational Actors in the Post-Maastricht Era (Oxford: Oxford University Press), 289-303.

Burns, C. (2004) 'Codecision and the European Commission: A Study of Declining Influence?' Journal of European Public Policy, Vol. 11, No. 1, pp. 1-18.

Busuioc, M., Groenleer, M., and Trondal, J. (eds) (2012) The Agency Phenomenon in the European Union (Manchester: Manchester University Press).

Christiansen, T., et al. (2013) 'Non-Legislative Rule Making After the Lisbon Treaty: Implementing the New System of Comitology and Delegated Acts'. European Law Journal, Vol. 19, No. 1, pp. 42-56. 
Commission (1990) Industrial Policy in an Open and Competitive Environment: Communication of the Commission to the Council and to the European Parliament. Com (90) 556 final.

Commission (2010a) Communication From the Commission ...: An Integrated Industrial Strategy for the Globalisation Era Putting Competitiveness and Sustainability at Centre Stage. Com (2010) 614 final.

Commission (2010b) Communication From the Commission...: Reinforcing Economic Policy Coordination. Com (2010) 250 final.

Commission (2012) Communication From the Commission...: A Stronger European Industry for Growth and Economic Recovery. Com (2012) 582 final.

Commission (2013) Communication From the Commission...Commission Work Programme 2014. Com (2013) 739 final.

Commission (2014a) Communication From the Commission...: For a European Industrial Renaissance. Com (2014) 14 final.

Commission (2014b) Communication From the Commission...: An Investment Plan for Europe. Com (2014) 0903 final.

Commission (2014c) Communication From the Commission on the European Citizens' Initiative "Water and Sanitation are a Human Right! Water is a Public Good, Not a Commodity!". Com (2014) 177 final.

Commission (2014d) Communication From the Commission... Commission Work Programme 2015: A New Start. Com (2014) 910 final.

Commission (2015a) Proposal for a Regulation of the European Parliament and of the Council of the European Union on the European Fund for Strategic Investments and Amending Regulations (EU) No 1291/2013 and (EU) No 1316/2013. Com (2015), 10 final, 2015 /0009.

Commission (2015b) Green Paper: Building a Capital Markets Union. Com (2015) 63 final.

Commission (2015c) Energy Union Package. Communication From the Commission... A Framework Strategy for a Resilient Energy Union with a Forward-Looking Climate Change Policy. Com (2015) 80 final.

Commission and European Parliament (2010) Interinstitutional Agreement on Relations Between the European Parliament and the European Commission. Official Journal of the European Union, L 304/47.

Copeland, P., et al. (2014) 'Policy Windows, Ambiguity and Commission Entrepreneurship: Explaining the Relaunch of the European Union's Economic Reform Agenda'. Journal of European Public Policy, Vol. 21, No. 1, pp. 1-19.

Costello, R., and Thomson, R. (2013) 'The Distribution of Power Among EU Institutions: Who Wins Under Codecision and Why?' Journal of European Public Policy, Vol. 20, No. 7, pp. 1025-39.

Cram, L. (1994) 'The European Commission as a Multi-Organization: Social Policy and IT Policy in the EU'. Journal of European Public Policy, Vol. 1, No. 2, pp. 195-217.

Dehousse, R. (2013) “The Community Method'. the EU's "Default” Operating System'. Notre Europe, Synthesis, Vol. , No. 11 February.

Dyrhauge, H. (2013) EU Railway Policy-Making on Track? (London: Palgrave Macmillan).

Egeberg, M., et al. (2015) 'The Quest for Order: Unravelling the Relationship Between the European Commission and European Union Agencies'. Journal of European Public Policy, Vol. 22, No. 5, pp. 609-29.

Eur-Lex (2015) 'Legislative Acts - Statistics'. Available at «http://eur-lex.europa.eu/statistics/ 2014/legislative-acts-statistics.html».

European Council (2010) Conclusions: 25/26 March. Brussels: General Secretariat of the Council.

European Council (2014a) Conclusions: Appendix 1 26/27 June. Brussels: General Secretariat of the Council.

European Council (2014b) Conclusions, 24 October. Brussels: General Secretariat of the Council. 
European Parliament (2014a) Conciliations and Codecision. Available at «www.europarl.europa. eu/code/about/statistics_en.htm».

European Parliament (2014b) Resolution of 12 March 2014 on the Commission Delegated Regulation of 12 December 2013 Amending Regulation (EU) No 1169/2011 on the Provision of Food Information to Consumers as Regards the Definition of "Engineered Nanomaterials". (C(2013)08887 - 2013/2997).

Hardacre, A. and Kaeding, M. (2011) Delegated and Implementing Acts: The New Comitology. EIPA Essential Guide. Available at «http://www.eipa.eu/files/repository/product/201112 12085434_Comitology_Brochure4EN_web.pdf».

Hartlapp, M., Metz, J. and Rauh, C. (2014) Which Policy for Europe? Power and Conflict Inside the European Commission (Oxford: Oxford University Press).

Häge, F.M., et al. (2013) 'The Effect of Codecision on Council Decision-Making: Informalization, Politicization and Power'. Journal of European Public Policy, Vol. 20, No. 7, pp. 953-71.

Hix, S., et al. (2013) 'Empowerment of the European Parliament'. Annual Review of Political Science, Vol. 16, pp. 171-89.

Huber, K., et al. (2013) 'Codecision: a Practitioner's View from Inside the Parliament'. Journal of European Public Policy, Vol. 20, No. 7, pp. 1040-55.

Kassim, H., Peterson, J., Bauer, M.W., Connolly, S., Dehousse, R., Hooghe, L., and Thompson, A. (2013) The European Commission of the Twenty-First Century (Oxford: Oxford University Press).

Kingdon, J. (1984) Agendas, Alternatives and Public Policies (Boston: Little Brown).

Majone, G. (2014) Rethinking the Union of Europe Post-Crisis: Has Integration Gone Too Far? (Cambridge: Cambridge University Press).

Nugent, N. and Rhinard, M. (2015) The European Commission, 2nd edn (London: Palgrave Macmilllan).

Nugent, N., et al. (2013) 'The European Commission and International Relations'. In Chang, M. et al. (eds) The European Commission in the Post-Lisbon Era of Crises (Berlin: Peter Lang).

Peterson, J. (2015) 'The Commission and the New Intergovernmentalism: Calm Within the Storm?' In Bickerton, C. et al. (eds) The New Intergovernmentalism: States and Supranational Actors in the Post-Maastricht Era (Oxford: Oxford University Press) pp. 185-207.

Ponzano, P., Hermanin, C. and Corona, D. (2012) The Power of Initiative of the European Commission: A Progressive Erosion?. Paris: Notre Europe, Studies and Reports, 89.

Princen, S. (2009) Agenda-Setting in the European Union (Basingstoke: Palgrave Macmillan).

Princen, S., et al. (2006) 'Crashing and Creeping: Agenda-Setting Dynamics in the European Union'. Journal of European Public Policy, Vol. 13, No. 7, pp. 1119-32.

Rasmussen, A. (2003) 'The Role of the Commission in Co-decision: A Strategic Facilitator Operating in a Situation of Structural Disadvantage'. European Integration Online Papers, Vol. 7, No. 10.

Rasmussen, A., et al. (2013) 'Twenty Years After Codecision in the European Union'. Special Issue of Journal of European Public Policy, Vol. 20, No. 7.

Rhinard, M. (2010) Framing Europe: The Policy Shaping Strategies of the European Commission (Boston: Martinus Nijhoff).

Rittberger, B., et al. (2011) 'Agency Governance in the European Union'. Special Issue of Journal of European Public Policy, Vol. 18, No. 6, pp. 780-9.

Schimmelfennig, F. (2015) 'What's New in "New Intergovernmentalism"? A Critique of Bickerton, Hodson and Puetter'. JCMS, Vol. 53, No. 4, pp. 723-30.

Stevens, H. (2004) Transport Policy in the European Union (Basingstoke: Palgrave Macmillan).

Force, T. (2010) 'Strengthening Economic Governance in the EU: Report of the Task Force to the European Council'. Brussels: Publications Office of the European Union, Vol. , No. 21 October.

Versluis, E., Van Kuelen, M. and Stephenson, P. (2011) Analyzing the European Union Policy Process (Basingstoke: Palgrave Macmillan). 
Voermans, W., et al. (2014) 'The Quest for Legitimacy in EU - Secondary Legislation'. The Theory and Practice of Legislation, Vol. 2, No. 1, pp. 5-32.

Wallace, H., et al. (2015) 'An Institutional Anatomy and Five Policy Modes'. In Wallace, H. et al. (eds) Policy-Making in the European Union (Oxford: Oxford University Press), pp. 72-112.

Wasserfallen, F. (2014) 'Political and Economic Integration in the EU: The Case of Failed Tax Harmonization'. JCMS, Vol. 52, No. 2, pp. 420-35.

Wille, A. (2013) The Normalization of the European Commission: Politics and Bureaucracy in the EU Executive (Oxford: Oxford University Press). 